\title{
Concentrate Mixture, Grass Pellets, Fodder Beets, or Barley as Supplements to Silage ad libitum for High-yielding Dairy Cows on Organic Farms
}

\begin{abstract}
Mogensen, L. and Kristensen, T. (Department of Agroecology, Danish Institute of Agricultural Sciences, Research Centre Foulum, P.O. Box 50, DK-8830 Tjele, Denmark). Concentrate mixture, grass pellets, fodder beets, or barley as supplements to silage ad libitum for high-yielding dairy cows on organic farms. Accepted September 12, 2003. Acta Agric. Scand., Sect. A, Animal Sci. 53: 186-196, 2003. (C) 2003 Taylor \& Francis.
\end{abstract}

In Denmark, organic feeding is typically based on homegrown feed with a high proportion of roughage. Which crop to grow and use as supplementary feed is investigated in this paper. In three experiments, barley (B) was compared with another type of supplementary feed: a concentrate mixture $(C)$, grass pellets $(\mathrm{G})$, or fodder beets $(\mathrm{F})$. The concentrate mixture resulted in a higher $(P=0.002)$ milk yield $(25.9$ vs. $23.7 \mathrm{~kg})$, a tendency of a lower $(P=0.07)$ fat content $(4.08 \mathrm{vs.} 4.25 \%)$, and a higher $(P=0.006)$ ECM yield $(25.7$ vs. $24.1 \mathrm{~kg})$ compared to feeding barley as supplement at the same energy level. Grass pellets resulted in a lower $(P=0.01)$ milk fat content $(3.74$ vs. $4.07 \%)$, a tendency of a lower $(P=0.12)$ protein content $(3.14$ vs. $3.23 \%)$, but no different milk or ECM yield compared to feeding barley as supplement at the same dry matter level. Fodder beet tended to decrease $(P=0.12)$ the milk yield $(20.7$ vs. $22.0 \mathrm{~kg})$, and the ECM yield $(P=0.05)$ was lower $(21.5$ vs. $22.9 \mathrm{~kg})$ whereas the composition of the milk was unaffected compared to the total mixed ration with barley.

\section{Lisbeth Mogensen* and Troels Kristensen}

Department of Agroecology, Danish Institute of Agricultural Sciences, Research Centre Foulum, P.O. Box 50, DK-8830 Tjele, Denmark

Key words: Health, homegrown, milk yield, organic feeding, supplementary feed.

\section{Introduction}

According to the new EU legislation, effective as of 2005 (Council for the European Union, 1999), the diet of organic dairy herds must be based entirely on organically grown feed. With regard to supplementary feed, the choice of which crop to grow, or alternatively

*Corresponding author. to buy, must be evaluated by comparing milk yield responses, prices, and crop yield per hectare.

An experiment, carried out by Mogensen \& Kristensen (2002), showed unexpectedly that barley on a net energy basis could replace rape seed cake as a supplement to clover grass silage ad libitum without milk yield reduction. This was surprising as the rape seed cake supplement provided a more balanced ration compared to the supplement of starch from barley. As with rape seed cake a comprehensive purchased 
organic concentrate mixture must supply the ration with adequate fatty acids and protein.

When the organic farmer has to provide $100 \%$ organic feed it will be logical to increase the level of nutrition from pasture and clover grass silage in the ration, as clover grass has a high predicted crop yield (Mogensen et al., 1999). However, clover grass from cuts late in the season can be difficult to digest. Harvesting as grass pellets is a means of increasing the quality of the surplus grass. An experiment by Aaes (1991) showed that $5.5 \mathrm{~kg}$ DM of grass pellets could replace $5.5 \mathrm{~kg}$ DM of barley without milk yield reduction even though the energy content was lower in the grass pellets than in barley. Fodder beets are another attractive crop in an organic system based on self-supply as they too have a high predicted crop yield. Furthermore, fodder beets have traditionally shown a positive effect on milk fat yield (Birkenmaier et al., 1996).

The aim of the present experiments is to compare different types of organic supplementary feed: barley versus concentrate mixture, grass pellets, or fodder beets with regard to milk yield response. It is further investigated whether any of the rations will result in health problems indicated by clinical illness treated by the vet, higher somatic cell counts (SCC), or claw problems.

\section{Materials and methods}

Three experiments (I, II, and III) were conducted during an eight-week period from December 1999 to March 2000 on three commercial, organic dairy farms (I, II, and III). All farms had a loose-housing system with slatted floors and straw bedded cubicles/bedded mattresses in the cubicles. The average milk yield per cow per year was $7,900 \mathrm{~kg}(4.06 \%$ fat and $3.34 \%$ protein) on farm I, 8,000 $\mathrm{kg}(4.17 \%$ fat and $3.28 \%$ protein) on farm II, and 7,000 $\mathrm{kg}(4.19 \%$ fat and $3.28 \%$ protein) on farm III.

\section{Treatments}

In each experiment barley as supplementary feed was compared with another type of supplementary feed. The planned intake of supplementary feed is shown in Table 1. In experiment I, barley (B) $(5.4 \mathrm{~kg} \mathrm{DM})$ was compared with a concentrate mixture $(\mathrm{C})$ on an isoenergetic basis. In experiment II, barley $(3.6 \mathrm{~kg} \mathrm{DM})$ was compared with grass pellets $(G)$ on the same dry matter basis. In experiments I and II, the ad libitum feed consisted of a mixture of clover grass silage and whole crop silage. In experiment III, two totally mixed rations (TMR) based on silage with either barley (3.6 $\mathrm{kg} \mathrm{DM})$ or fodder beets $(\mathrm{F})$ on an iso-energetic basis were compared. The chemical composition and feeding value of the different feedstuffs are shown in Table 2.

\section{Animals}

In each experiment the cows were blocked according to number of lactations, days from calving, and expected days to next calving and then randomly allocated to treatments. All cows were Danish Holstein. Only cows less than 36 weeks from calving at the beginning of the experiment were included. In experiment I, 97 cows with a mean of $25.1 \mathrm{~kg}$ milk per day and $584 \mathrm{~kg}$ mean live weight were included at the beginning of the experiment, and 9 cows were included at calving. In experiment II, 49 cows with a mean of $26.8 \mathrm{~kg}$ milk and $553 \mathrm{~kg}$ mean live weight were included at the beginning of the experiment, and 10 cows were included at calving. In experiment III, 75 cows with a mean of $24.8 \mathrm{~kg}$ milk and $603 \mathrm{~kg}$ mean live weight were included at the beginning of the experiment, and 6 cows were included at calving.

\section{Feeding}

Before the experimental period, all cows in each herd received same amount and type of supplementary feed for two weeks. For cows which were included in the

Table 1. Planned amount of experimental feed in $\mathrm{kg}$ dry matter per cow per day (Scandinavian feed unit in brackets)

\begin{tabular}{|c|c|c|c|c|c|c|}
\hline \multirow{2}{*}{$\begin{array}{l}\text { Experiment } \\
\text { Treatment }\end{array}$} & \multicolumn{2}{|l|}{1} & \multicolumn{2}{|l|}{ II } & \multicolumn{2}{|l|}{ III } \\
\hline & $\begin{array}{l}\text { C } \\
\text { Concentrate }\end{array}$ & $\begin{array}{l}\text { B } \\
\text { Barley }\end{array}$ & $\begin{array}{l}\text { G } \\
\text { Grass pellets }\end{array}$ & $\begin{array}{l}\text { B } \\
\text { Barley }\end{array}$ & $\begin{array}{l}\text { F } \\
\text { Fodder beets }\end{array}$ & $\begin{array}{l}\text { B } \\
\text { Barley }\end{array}$ \\
\hline Barley & 0 & $5.4(6.0)$ & 0 & $3.6(4.0)$ & 0 & $3.6(4.0)$ \\
\hline Concentrate mixture ${ }^{1)}$ & $5.1(6.0)$ & 0 & - & - & - & - \\
\hline Grass pellets & - & - & $3.6(2.2)$ & 0 & - & - \\
\hline Fodder beets & - & - & - & - & $5.0(4.0)$ & 0 \\
\hline
\end{tabular}

1) $35 \%$ wheat bran, $29 \%$ peas, $13.5 \%$ soya beans, $10 \%$ lupins, $7 \%$ lucerne, $3.5 \%$ triticale. 
Table 2. Chemical composition, energy and protein content of the different foodstuffs, g per kg DM

\begin{tabular}{|c|c|c|c|c|c|c|c|c|c|c|c|}
\hline & \multirow[b]{2}{*}{ Fatty acids } & \multirow[b]{2}{*}{ Sugar } & \multirow[b]{2}{*}{ Starch } & \multirow[b]{2}{*}{ Dig. cell walls } & \multicolumn{3}{|c|}{ Energy content } & \multicolumn{3}{|c|}{ Protein content } & \multirow[b]{2}{*}{ Dig. $^{6)} \%$} \\
\hline & & & & & $\begin{array}{l}\mathrm{DE}^{1)} \\
\mathrm{MJ}\end{array}$ & $\begin{array}{l}\mathrm{ME}^{2)} \\
\mathrm{MJ}\end{array}$ & $\begin{array}{l}N E^{3)} \\
S F U\end{array}$ & $\begin{array}{l}\text { Crude } \\
\text { protein }\end{array}$ & $\mathrm{AAT}^{4)}$ & $\mathrm{PBV}^{5)}$ & \\
\hline \multicolumn{12}{|l|}{ Experiment I } \\
\hline Barley & 28 & 20 & 574 & 122 & 15.2 & 13.1 & 1.11 & 124 & 97 & -39 & - \\
\hline Concentrate mixture & 51 & 74 & 139 & 269 & 15.5 & 13.2 & 1.18 & 236 & 122 & 49 & - \\
\hline Clover grass silage & 18 & 29 & 15 & 505 & 13.8 & 11.8 & 0.92 & 174 & 71 & 42 & 77.5 \\
\hline Wheat whole crop & 12 & 20 & 271 & 242 & 11.5 & 10.0 & 0.59 & 80 & 62 & -30 & 63.0 \\
\hline \multicolumn{12}{|l|}{ Experiment II } \\
\hline Barley & 28 & 20 & 581 & 124 & 15.2 & 13.1 & 1.12 & 119 & 98 & -45 & - \\
\hline Grass pellets & 20 & 130 & 0 & 298 & 11.5 & 9.8 & 0.63 & 170 & 82 & 24 & 63.3 \\
\hline Clover grass silage & 17 & 26 & 10 & 518 & 13.8 & 11.8 & 0.92 & 166 & 71 & 37 & 83.1 \\
\hline Barley/pea whole & 12 & 24 & 196 & 344 & 12.3 & 10.6 & 0.79 & 133 & 67 & 19 & 70.4 \\
\hline \multicolumn{12}{|l|}{ Experiment III } \\
\hline Barley & 28 & 20 & 574 & 122 & 15.2 & 13.1 & 1.11 & 111 & 97 & -51 & - \\
\hline Fodder beets & 0 & 489 & 0 & 144 & 12.6 & 10.9 & 0.81 & 74 & 77 & -60 & - \\
\hline Clover grass silage & 18 & 22 & 15 & 442 & 12.4 & 10.7 & 0.79 & 147 & 68 & 22 & 74.4 \\
\hline Maize whole crop & 14 & 21 & 248 & 399 & 12.5 & 10.9 & 0.80 & 79 & 80 & -62 & 73.8 \\
\hline Pea whole crop & 9 & 19 & 137 & 224 & 12.4 & 10.6 & 0.54 & 145 & 52 & 50 & 58.1 \\
\hline
\end{tabular}

1) Digested energy.

2) Metabolizable energy.

3) Net energy.

4) Amino acids absorbed in the small intestine.

5) Protein balance in rumen.

6) Digestibility in organic matter. 
- Paper IIISilage supplements for dairy cows on organic farms

experiment at calving, the level of supplementary feed was increased to maximum level over the first two weeks of lactation. In experiments I and II, the supplementary feed was fed individually to each cow, according to the different treatments, by an automatic feeding station with a minimum of three visits per cow per day. In experiments I and II, a mixture of clover grass silage, whole crop silage and small amounts of concentrate feed was made in a mixer wagon and fed ad libitum once a day. In experiments I and II all cows were housed in one group.

In experiment III, the cows in the two treatments were housed in two separated groups in the yard, and the two rations were fed once a day at the fodder trough in front of each group. The feed was mixed by a mixer wagon before feeding. The silage used in all three experiments was conserved without use of additives. The clover grass silage had been wilted in advance of cutting and the whole crop silage was harvested directly. All roughage was stored in horizontal silos.

\section{Recordings}

In experiments I and II, the intake of supplementary feed was recorded for the individual cow for $24 \mathrm{~h}$ each day. The intake of ad libitum feed was recorded for all cows in the experiment for $24 \mathrm{~h}$ every second week. The average intake of the ad libitum feed per cow per day was calculated as the total intake of ad libitum feed divided by number of cows in the experiment. In experiment III, the intake and composition of the TMR was recorded for all cows in each treatment for $24 \mathrm{~h}$ every second week.

Silage was analysed for dry matter, ash, crude protein, starch, crude fibre (Helrich 1990), and in vitro digestibility of organic matter (Tilley \& Terry, 1963) every second week. AAT, PBV, fatty acids, sugar, digestible cell walls and energy values were calculated according to Strudsholm et al. (1997). The supplementary feeds were analysed once, based on an aggregated sample compound of a sample from every second week. In addition to the same analysis as for silage, the concentrate mixture was analysed for crude fat.

Cows were weighed and body condition score (1-5 point, with 0.5 point interval) was estimated before the experiment (week 0), once during the experiment (week 5), and just after the end of the experiment (week 9). Milk yield and content of fat, protein, urea, and SCC were examined for $24 \mathrm{~h}$ every second week. All veterinary treatments were recorded by the local vet. All cows were claw trimmed by a professional trimmer after the experimental period. For the description of the claw health the National Danish Claw Recording Scheme was used.

\section{Statistical analyses}

Energy-corrected milk (ECM) was calculated as defined by Sjaunja et al. (1990), $E C M=$ Milk yield $*(383 *$ fat $\%+242 *$ protein $\%+780.8) / 3140$. Effect of treatment on milk yield and urea content was analysed for each experiment, separately, by the General Linear Model (SAS, 1990) based on the average yield per cow during the experimental period and according to model 1

$$
\begin{aligned}
\text { (1) Yield }= & \text { treatment }+ \text { parity }+ \text { parity } * \text { treatment } \\
& + \text { days in milk }+ \text { days in milk } * \text { parity } \\
& + \text { yield before experiment }
\end{aligned}
$$

where yield is the average milk yield per cow per day ( $\mathrm{kg} \mathrm{ECM}, \mathrm{kg}$ milk, fat percentage, $\mathrm{kg}$ fat yield, protein percentage, $\mathrm{kg}$ protein yield, urea content); treatment is the two different supplementary feeds within experiment; parity is first calf or older; days in milk is the average interval per cow from calving (covariate), and yield before the experiment is the last milk yield recording before the experiment standardized to an average of 0 and a standard deviation of 5 . For cows included at calving during the experiment a value of 0 was used.

The effect of the milk production level, either high or low, at the last milk yield recording before the experiment on the response of the treatment in the experimental period has been examined in an independent analysis. The cows were divided into two groups within parity with the same number of cows according to their production in the pre-period. An analogous study examined the effect of the stage of lactation (either early or late) at the beginning of the experiment on the response to the treatment. The cows were divided into two groups within parity with the same number of cows according to days postpartum at the beginning of the experiment.

Live weight gain per cow during the experimental period was calculated as the difference between the weight at the end and at the beginning of the experiment and analysed by model 1 . Live weight at the first registration at the beginning of the experiment was used as covariate. Similarly, change in body condition score was calculated as the difference between the body condition score at the end and at the beginning of the experiment and analysed by model 1 .

SCC was transformed by the logarithm. A simple average per cow of the four registrations during the experimental period was analysed by the same model as milk yield. $\log (\mathrm{SCC})$ from the latest registration before the experiment was included as a covariate.

Health and claw problems were tested by an $\chi^{2}$ test (SAS, 1990). 


\section{Mogensen and T. Kristensen}

\section{Results}

\section{Daily feed intake per cow}

Daily dry matter (DM) intake per cow together with calculated energy and nutrient intake for the two treatments in each experiment is shown in Table 3. In experiment I, the daily intake of the ad libitum feed was $15.1 \mathrm{~kg}$ DM with $58 \%$ from wheat whole crop and $28 \%$ from clover grass silage, while the remaining $14 \%$ was rape seed cake and beet pellets. Intake in treatment $\mathrm{C}$ was $5.2 \mathrm{~kg}$ DM concentrate mixture, equivalent to $6.1 \mathrm{SFU}$, and the intake in treatment B was 5.1 $\mathrm{kg}$ DM barley, equivalent to 5.7 SFU. Barley was fed at a lower level than planned, owing to problems with the adjustment of the available amount of barley fed from the feeding station. The available amount of supplementary feed was consumed completely.
In experiment II, the daily intake of the ad libitum feed was $15.3 \mathrm{~kg}$ DM with $43 \%$ barley/pea whole crop and $41 \%$ clover grass silage, while the remaining $16 \%$ was rape seed cake, beet pellets, and fish meal. In treatment $\mathrm{G}$ the intake was $3.1 \mathrm{~kg} \mathrm{DM}$ from grass pellets, equivalent to $2.0 \mathrm{SFU}$, while the intake in treatment B was $3.3 \mathrm{~kg}$ DM from barley, equivalent to 3.7 SFU.

In experiment III, the daily intake of the TMR was 21.4 and $21.2 \mathrm{~kg} \mathrm{DM}$ in treatment $\mathrm{F}$ and $\mathrm{B}$, respectively. In both TMRs, $30 \%$ of the DM was clover grass silage, $15 \%$ maize/pea whole crop, $21 \%$ lucerne grass pellets, and $18 \%$ was barley and rape seed cake. Furthermore, the TMR in treatment $F$ includes $3.6 \mathrm{~kg} \mathrm{DM}$ from fodder beets, equivalent to 2.9 SFU, and the TMR in treatment B includes $3.4 \mathrm{~kg}$ DM from barley, equivalent to $3.8 \mathrm{SFU}$.

Table 3. Daily feed intake in kg dry matter (DM) per cow and calculated energy and nutrient intake

\begin{tabular}{|c|c|c|c|c|c|c|}
\hline \multirow{2}{*}{$\begin{array}{l}\text { Experiment } \\
\text { Treatment }\end{array}$} & \multicolumn{2}{|l|}{1} & \multicolumn{2}{|l|}{ II } & \multicolumn{2}{|l|}{ III } \\
\hline & Concentrate & Barley & Grass pellets & Barley & Fodder beets & Barley \\
\hline \multicolumn{7}{|c|}{ Treatment feed, kg DM per cow } \\
\hline Barley & 0 & 5.1 & 0 & 3.3 & 0 & 3.4 \\
\hline Concentrate mixture & 5.2 & 0 & - & - & - & - \\
\hline Grass pellets & - & - & 3.1 & 0 & - & - \\
\hline Fodder beets & - & - & - & - & 3.6 & 0 \\
\hline \multicolumn{7}{|c|}{ Ad libitum feed, kg DM per cow } \\
\hline Clover grass silage & 4.3 & 4.3 & 6.2 & 6.2 & 6.4 & 6.4 \\
\hline Whole crop silage & $8.8^{1)}$ & $8.8^{1)}$ & $6.5^{2)}$ & $6.5^{2)}$ & $3.1^{3)}$ & $3.1^{3)}$ \\
\hline Lucerne pellets & - & - & - & - & 4.4 & 4.4 \\
\hline Rape seed cake & 1.3 & 1.3 & 1.5 & 1.5 & 1.7 & 1.7 \\
\hline Beet pellets & 0.7 & 0.7 & 0.8 & 0.8 & - & - \\
\hline Straw & - & - & 0.2 & 0.2 & - & - \\
\hline Fishmeal & - & - & 0.1 & 0.1 & - & - \\
\hline Barley & _- & _- & - & - & 2.2 & 2.2 \\
\hline Total & 15.1 & 15.1 & 15.3 & 15.3 & - & - \\
\hline \multicolumn{7}{|l|}{ Total intake } \\
\hline Dry matter, kg & 20.5 & 20.4 & 18.6 & 18.7 & 21.4 & 21.2 \\
\hline Net energy, SFU & 17.5 & 17.1 & 15.9 & 17.6 & 17.2 & 18.1 \\
\hline Digested energy, MJ & 272 & 269 & 239 & 253 & 272 & 279 \\
\hline Metabolizable energy, MJ & 233 & 231 & 204 & 217 & 234 & 240 \\
\hline \multicolumn{7}{|l|}{ Per kg DM, g } \\
\hline Fatty acids & 27 & 21 & 25 & 27 & 25 & 29 \\
\hline Starch & 157 & 268 & 74 & 174 & 94 & 188 \\
\hline Sugar & 44 & 30 & 51 & 33 & 122 & 44 \\
\hline AAT & 86 & 79 & 81 & 84 & 73 & 76 \\
\hline PBV & 12 & -10 & 28 & 16 & 11 & 12 \\
\hline Crude protein & 156 & 128 & 167 & 158 & 141 & 147 \\
\hline Digestible crude protein & 115 & 89 & 126 & 121 & 98 & 104 \\
\hline Digestible cell walls & 318 & 281 & 399 & 368 & 293 & 291 \\
\hline
\end{tabular}

\footnotetext{
1) Wheat whole crop.

2) Barley/pea whole crop.

3) $60 \%$ maize and $40 \%$ pea whole crop silage.
} 
- Paper IIISilage supplements for dairy cows on organic farms

Table 4. Daily milk yield, energy corrected milk yield (ECM), content of fat, protein, urea, and somatic cell counts (SCC) in three experiments with different supplement, LS means

\begin{tabular}{|c|c|c|c|c|c|c|c|c|c|}
\hline \multirow{2}{*}{$\begin{array}{l}\text { Experiment } \\
\text { Treatment }\end{array}$} & \multicolumn{3}{|l|}{1} & \multicolumn{3}{|l|}{ II } & \multicolumn{3}{|l|}{ III } \\
\hline & Concentrate & Barley & $P$ & Grass pellets & Barley & $P$ & Fodder beets & Barley & $P$ \\
\hline Number of cows & 53 & 53 & & 30 & 29 & & 41 & 40 & \\
\hline ECM, kg & 25.7 & 24.1 & 0.006 & 25.7 & 26.4 & 0.43 & 21.5 & 22.9 & 0.05 \\
\hline Milk, kg & 25.9 & 23.7 & 0.002 & 27.2 & 26.7 & 0.57 & 20.7 & 22.0 & 0.12 \\
\hline Fat, $g$ & 1046 & 996 & 0.05 & 1014 & 1077 & 0.10 & 904 & 966 & 0.07 \\
\hline Fat, \% & 4.08 & 4.25 & 0.07 & 3.74 & 4.07 & 0.01 & 4.41 & 4.47 & 0.71 \\
\hline Protein, g & 847 & 787 & 0.003 & 850 & 854 & 0.89 & 682 & 733 & 0.06 \\
\hline Protein, \% & 3.30 & 3.35 & 0.21 & 3.14 & 3.23 & 0.12 & 3.31 & 3.39 & 0.25 \\
\hline SCC, 1000 & 85 & 100 & 0.23 & 83 & 83 & 0.99 & 115 & 170 & 0.06 \\
\hline Urea, mM & 4.78 & 3.93 & 0.0001 & 4.56 & 4.12 & 0.0001 & 3.40 & 4.30 & 0.0001 \\
\hline
\end{tabular}

$P=$ effect of treatment within the experiment.

\section{Daily milk yield, SCC, and urea}

Daily milk yield, energy corrected milk yield, content of fat and protein, urea, and somatic cell counts in the three experiments are shown in Table 4. In experiment $\mathrm{I}$, cows in treatment $\mathrm{C}$ have higher milk yield $(P=$ $0.002)$ than those in treatment B $(25.9$ vs. $23.7 \mathrm{~kg})$. The fat percentage tended to be lower $(P=0.07)$ in treatment $\mathrm{C}$ ( 4.08 vs. $4.25 \%$ ), and the protein percentage $(P=0.21)$ was no different between the two treatments ( 3.30 vs. $3.35 \%$ ). The ECM yield was higher $(P=0.006)$ in treatment $\mathrm{C}$ than in treatment B $(25.7$ vs. $24.1 \mathrm{~kg})$. The mean $\operatorname{SCC}(P=0.23)$ was no different between treatments. The mean urea level was higher $(P=0.0001)$ in treatment $\mathrm{C}$ than in treatment B $(4.78$ vs. $3.93 \mathrm{mM})$.

The difference in ECM yield between treatment $\mathrm{C}$ and $\mathrm{B}$ was higher for cows in early lactation than for cows in late lactation and higher for older cows than for first parity cows (Fig. 1).

In experiment II, the milk yield was not significantly different between the two treatments $(P=0.57)$ even though treatment $G$ had 1.7 SFU less energy intake than treatment B assuming the same ad libitum intake of roughage (Table 3). The milk fat content was only $3.74 \%$ in treatment $\mathrm{G}$ against $4.07 \%$ in treatment B $(P=0.01)$, and the protein content tended to be lower $(P=0.12)$ in treatment $\mathrm{G}$ as well $(3.14$ vs. $3.23 \%)$. However, the ECM yield was not significantly different between treatments $(P=0.43)$. The mean SCC was not affected by treatments $(P=0.99)$. The milk urea level was higher $(P=0.0001)$ in treatment $\mathrm{G}$ than in treatment B (4.56 vs. 4.12$)$.

At the end of experiment II, based on the last milk yield recording, the effects obtained during the experiment were even clearer. Treatment $\mathrm{G}$ tended to have a higher $(P=0.08)$ milk yield $(26.9$ vs. $25.3 \mathrm{~kg})$, a lower $(P=0.003)$ milk fat content $(3.83$ vs. $4.21 \%)$, and a tendency to a lower $(P=0.07)$ protein content (3.23 vs.

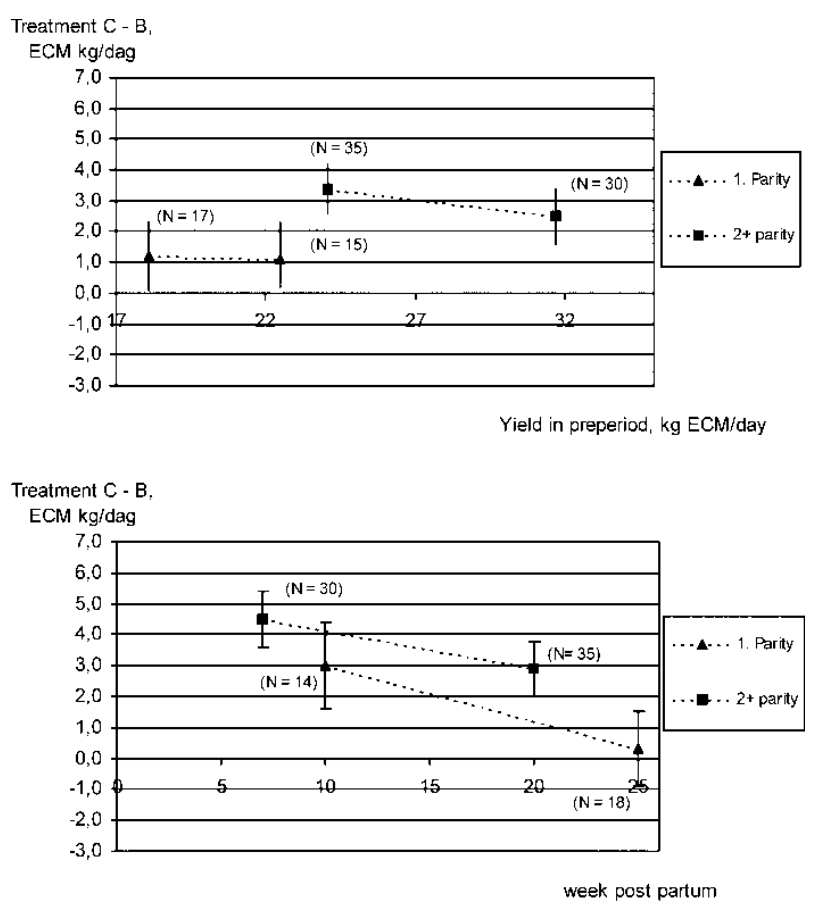

Fig. 1. Experiment I: Differences in ECM yield between concentrate treatment and barley treatment according to characteristics of the pre-experimental grouping for low and high yields and in earliest and latest stage of lactation.

$3.31 \%)$. However, the ECM yield was not $(P=0.99)$ affected (25.8 vs. $25.7 \mathrm{~kg})$. The difference in ECM yield between treatment $B$ and $G$ was decreased with increased weeks postpartum for first parity cows, while the opposite was seen for older cows (Fig. 2).

In experiment III, the ECM yield was $1.4 \mathrm{~kg}$ higher $(P=0.05)$ in treatment B than in treatment F. Neither milk fat content $(P=0.71)$ nor protein content $(P=$ $0.25)$ was significantly different between the two treatments, but the higher milk yield of $1.3 \mathrm{~kg}$ for treatment $\mathrm{B}$ tended to be significant $(P=0.12)$. This 


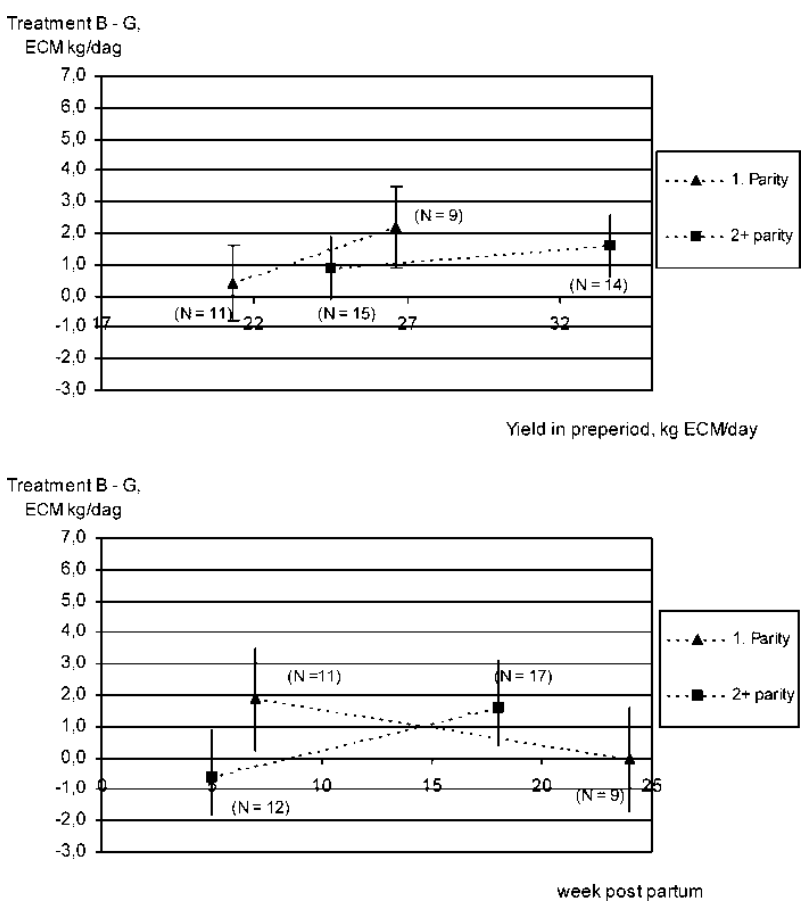

Fig. 2. Experiment II: Differences in ECM yield between barley treatment and grass pellets treatment according to characteristics of the pre-experimental grouping for low and high yields and in earliest and latest stage of lactation.

could partly be explained by a higher energy intake of $0.9 \mathrm{SFU}$ in treatment $\mathrm{B}$. The mean SCC was higher in treatment $\mathrm{B}$ than in treatment $\mathrm{F}(P=0.06)$. The mean urea level was higher in treatment $\mathrm{B}$ than in treatment $\mathrm{F}(P=0.0001)$. The difference in ECM yield between treatment $\mathrm{B}$ and $\mathrm{F}$ was much greater for first parity than for older cows (Fig. 3).

\section{Health and live weight gain}

The prevalence of different disorders is shown in Table 5. There was no significant difference in the overall disease incidences between treatments. There was some variation between experiments in the level of claw problems. However, there was no significant difference between treatments. Live weight gain $(P>0.64)$ during the experimental period was not affected by the different treatments in any of the experiments (average: $-4 \mathrm{~kg},+28 \mathrm{~kg}$ and $+11 \mathrm{~kg}$ in experiment $\mathrm{I}$, II and III, respectively). Neither were changes in body condition score $(P>0.86)$ during the experimental period affected by the different treatments in any of the experiments (average: -0.2 point, -0.1 point and +0.1 point in experiment I, II and III, respectively).
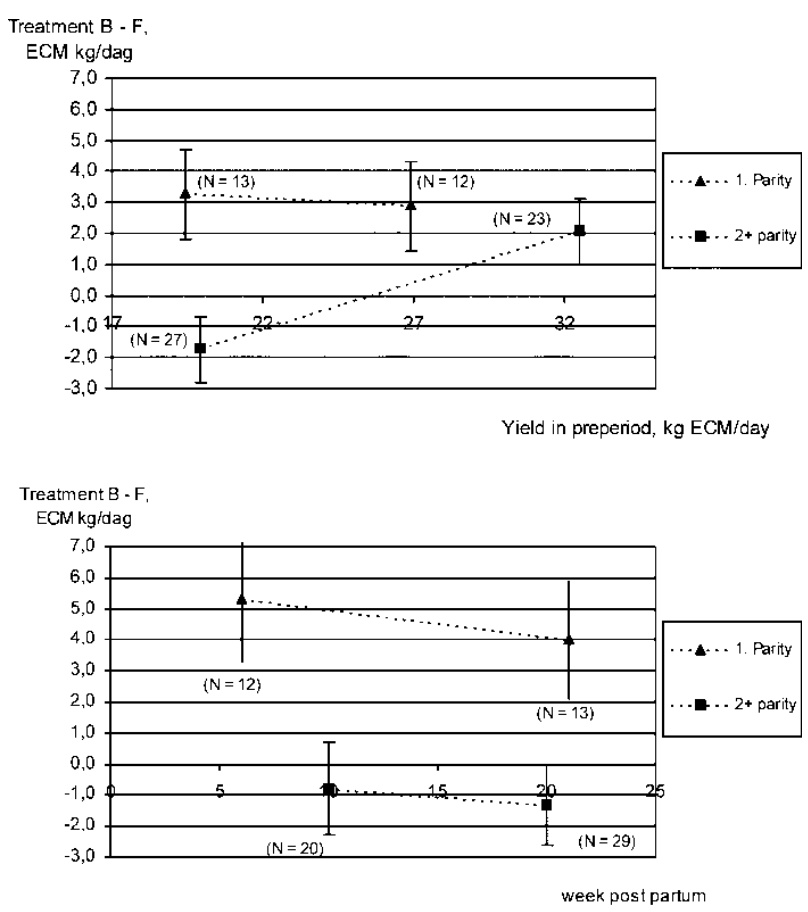

Fig. 3. Experiment III: Differences in ECM yield between barley treatment and fodder beets treatment according to characteristics of the pre-experimental grouping for low and high yields and in earliest and latest stage of lactation

\section{Discussion}

A balanced diet with supplement of a concentrate mixture increased milk yield compared to a more unbalanced diet with supplement of barley.

Cows on treatment $\mathrm{C}$ had 7\% higher ECM milk yield than cows on treatment B and only a part of this difference could be explained by the estimated $(2 \%)$ higher energy intake caused by differences in intake from the supplementary feed. As the same fill of the total ration was reached in both treatments, the same intake of ad libitum feed was assumed in the two treatments according to the feed intake capacity (Kristensen 1983, 1995). The findings were in contrast to an earlier experiment comparing $2.5 \mathrm{SFU}$ rape seed cake and 2.5 SFU barley as supplement. This experiment showed no difference in milk yield between the two types of supplementary feed (Mogensen \& Kristensen, 2002). The concentrate mixture in the present experiment, as with the rape seed cake, added protein and fatty acids to the ration. An explanation for the different findings could be that in the experiment by Mogensen \& Kristensen (2002) the amount of supplementary feed compared was smaller than in the present experiment. Furthermore, a lower proportion of clover grass silage in the ad libitum feed in the present experiment resulted in a less favourable nutrient composition, in particular for the barley diet with a low level of crude protein, a low protein balance 
- Paper IIISilage supplements for dairy cows on organic farms

Table 5. Different types of disorders during the eight-week experimental period, number of cows treated by vet

\begin{tabular}{|c|c|c|c|c|c|c|}
\hline \multirow{2}{*}{$\begin{array}{l}\text { Experiment } \\
\text { Treatment }\end{array}$} & \multicolumn{2}{|l|}{1} & \multicolumn{2}{|l|}{ II } & \multicolumn{2}{|l|}{ III } \\
\hline & Concentrate & Barley & Grass pellets & Barley & Fodder beets & Barley \\
\hline Total number of cows at risk & 53 & 53 & 30 & 29 & 41 & 40 \\
\hline Mastitis & 1 & 5 & 0 & 2 & 5 & 3 \\
\hline Reproductive disorders $^{11}$ & 1 & 1 & 0 & 0 & 0 & 0 \\
\hline Digestion/metabolic disorders ${ }^{2)}$ & 1 & 0 & 1 & 0 & 3 & 0 \\
\hline Limb disorders $^{3)}$ & 4 & 3 & 0 & 0 & 1 & 1 \\
\hline Problems at calving ${ }^{4)}$ & 0 & 0 & 0 & 1 & 1 & 1 \\
\hline Disorders in total ${ }^{5)}$ & 5 & 9 & 1 & 3 & 7 & 5 \\
\hline
\end{tabular}

1) Uterus inflammation, retained placenta.

2) Milk fever, abomasitis, poisoning, ketosis, displaced abomasums.

3) Foot rot, pressure bruise.

4) Abortion, difficult calving with assistance.

5) Each cow is counted only once.

in the rumen, a low level of amino acids absorbed from the small intestine, and a high level of starch.

A level of crude protein below $16 \%$ of $\mathrm{DM}$ is thought to decrease feed intake (Roffler \& Tracker, 1983). In the present experiment, the level of crude protein was $13 \%$ in the barley diet versus $16 \%$ in the concentrate diet. Roffler \& Tracker (1983) found that the intake of energy was increased by $15 \%$ by increasing the level of crude protein from $14 \%$ to $17 \%$, and milk yield was increased by $10 \%$.

Other studies have also observed an improved intake of energy and a concomitant improvement of milk yield from increased concentration of dietary crude protein (Cressman et al., 1980; Edwards et al., 1980; Lundquist et al., 1981). However, Agabriel et al., 1997 compared iso-energetic supply of rolled wheat or a concentrate mixture to a restricted amount of grass silage and found that milk yield was higher for the mixture even though energy intake was the same. This higher milk yield could be related to a better digestibility because of a slower degradation in the rumen of the mixture diet, which reduces digestive interactions. Alternatively, the higher milk yield could be due to the higher nitrogen supplementation, which may have improved the diet digestibility (Weisberg, 1997).

Fibrous supplement of grass pellets could replace starchy supplement of barley on an equal dry matter basis.

$3.6 \mathrm{~kg} \mathrm{DM}$ of grass pellets could replace $3.6 \mathrm{~kg} \mathrm{DM}$ of barley without milk yield reduction, even though cows in the grass pellet treatment had a $10 \%$ lower estimated energy intake than those in the barley treatment, owing to differences in energy intake from the supplement. The same intake of ad libitum feed was assumed in the two treatments according to the feed intake capacity (Kristensen 1983, 1995). Both rations fulfil the nutrient recommendation for ration composition (Strudsholm et al., 1999) in almost every respect.

In agreement with the present experiment, Aaes (1991) found no difference in ECM yield between cows fed a supplement of $5.5 \mathrm{~kg}$ DM from grass pellets of high digestibility compared to a supplement of $5.5 \mathrm{~kg}$ DM of concentrate mixture even though the feed intake in terms of energy was lower for cows fed grass pellets. The positive effects on milk yield of grass pellets in the present experiment were found even though the digestibility of organic matter in the grass pellets was lower than in the experiment by Aaes (1991). As grass pellets have a small particle size, which results in a high rate of passage through the rumen, it is assumed that it is important to use grass pellets of high digestibility to achieve a reasonable utilisation of the cell walls from the grass pellets.

Several studies have compared fibrous and starchy carbohydrates as supplement to grass silage ad libitum . Some studies report an increased milk yield from fibrous supplement compared to starchy supplement (Thomas et al., 1986; Jackson et al., 1991; Huhtanen, 1993). These experiments all reported a higher intake of the ad libitum feed on the fibrous diet. However, due to allocation of supplementary feed at equal levels of dry matter, and thereby a lower energy supply from fibrous than from starchy supplement, only the experiment of Jackson et al. (1991) reported an overall increased energy intake on the fibrous treatment. The increased milk yield in the experiment by Jackson et al. (1991) can probably be explained by the additional energy intake in the fibrous diet. However, in the studies by Thomas et al. (1986) and Huhtanen (1993) the greater milk yield with the fibrous supplement, despite the same or a lower ME intake (Huhtanen, 1993), may be related to positive, associative effects 
from a combination of different carbohydrate sources as compared with barley alone.

Other studies report the same milk yield from fibrous supplement compared to the same DM or $\mathrm{kg}$ of starchy supplement (Castle et al., 1981; Mayne \& Gordon, 1984; Huhtanen, 1987; Phipps et al., 1987). In none of these experiments did the cows compensate for the lower energy intake from the fibrous supplement than from starchy supplement, as the intake of the ad libitum feed did not differ.

The effect of source of supplement increases in importance as the proportion of concentrate in the diet increases. More than $50 \%$ concentrate is needed in the diet to show effects of supplementary type on rumen fermentation (Visser, 1984; Murphy, 1989; Huhtanen, 1992). At a lower rate of concentrate supplementation to a grass-silage based diet the effect of supplement source (barley or fibre) on rumen $\mathrm{pH}$ and the rate of degradation of silage DM was fairly small even though the difference in supply of carbohydrate was large (Huhtanen, 1992).

In the present experiment, the milk fat percentage was higher for the barley ration than for the grass pellet ration. Traditionally, a supplement rich in starch will depress the milk fat percentage compared with a supplement rich in cell walls, as starch changes the fermentation to a more propionic acid type (Beukelen, 1983). However, there is also evidence from other studies that replacing barley with fibrous supplement by grass silage ad libitum may result in reduced milk fat content (Thomas et al., 1986; Huhtanen, 1987; Huhtanen, 1993). A similar tendency for a lower milk fat percentage was found for grazing cows supplied with fodder beet pellets instead of barley (Kristensen \& Aaes, 1998). In contrast, Castle et al. (1981), Mayne \& Gordon (1984), and Jackson et al. (1991) found that the source of the supplement affected nether milk fat content nor milk yield in $\mathrm{kg}$ terms.

At a higher concentrate to roughage ratio $(>50 \%)$ than the one in the above experiments $(35-50 \%)$, fibrous supplement has often resulted in a higher milk fat content than starchy supplements (Sutton et al., 1985; Phipps et al., 1987; Garnsworthy, 1989). According to the theory by Griinari et al. (1997) the milk fat synthesis in the mammary glands may be inhibited by trans-octadecenoic acids when the diets are low in fibre.

The milk protein percentage tended to be higher for the barley ration than for the grass pellet ration in the present experiment. Normally, starch stimulates the protein percentage in milk and Thomas et al. (1986), Phipps et al. (1987), and Huhtanen (1993) found that a supplement of starch instead of fibre to grass silage $a d$ libitum resulted in a higher milk protein percentage. However, Castle et al. (1981), Mayne \& Gordon
(1984), and Valk et al. (1990) found that fibrous supplement resulted in the same milk protein content as supply of starchy carbohydrate.

An explanation of a higher milk protein content could be a higher energy intake, as the energy level is the factor with greatest influence on the protein percentage in the milk (Spörndly, 1989). Visser et al. (1990) found that immediately after calving, milk protein content and energy balance were reduced for cows on a fibrous diet but not for cows on a starchy diet. However, 15 weeks after calving milk protein content and energy balance were at the same level for the two diets, but the opposite was seen in the present experiment. The cows fed grass pellets had a higher protein content in milk just after calving, but lower in late lactation. The lower protein content in the grass pellet treatment could also to some extent be a dilution effect (DePeters \& Cant, 1992) with a numerically higher milk yield and the same protein yield as in the barley treatment.

\section{A TMR with fodder beet resulted in a lower milk yield} than a TMR with barley.

The major explanation for this finding was the lower level of energy intake due to the anomalous quality of the fodder beets. The beets had a very high content of ash $(21 \%$ of DM) as well as a low content of DM $(14 \%)$, which resulted in an overestimation of the energy content, and resulted in fodder beet and barley being supplied at the same level of DM instead of energy. Treatment $\mathrm{F}$ resulted in a high level of sugar $(122 \mathrm{~g} / \mathrm{kg} \mathrm{DM})$ and treatment $\mathrm{B}$ in a high level of starch $(188 \mathrm{~g} / \mathrm{kg} \mathrm{DM})$, whereas the other nutrients were very similar in the two treatments.

Krohn \& Andersen (1979) and Moate et al. (1999) compared $6 \mathrm{~kg}$ DM from barley or fodder beets and 5 $\mathrm{kg}$ DM of barley or turnips (with a lower sugar content than fodder beet), respectively. They also found a higher milk yield from cows in the barley treatment. Furthermore, an experiment by Stensig et al. (1998) showed that neither the digestion of NDF nor the milk yield differ between diets with $20 \%$ DM from starch or sugar in TMRs primarily based on grass silage. In the present experiment, sugar makes up $12 \%$ of the DM in the beet ration and starch $19 \%$ of the DM in the barley ration.

Traditionally, the sugar in the beet ration is expected to stimulate the milk fat percentage, as the fermentation results in more butyric acid, which is an important input for milk fat synthesis in the udder. However, the milk fat percentage differed neither between the two treatments in our experiment nor in the experiment by Moate et al. (1999).

Health, SCC, and urea in milk. 
None of the rations resulted in health problems such as clinical illness treated by the vet, or claw problems. However, in experiment III the levels of SCC were significantly higher for the barley diet than for the fodder beet diet. Barnouin et al. (1995) confirmed these findings from herd studies, as high quantities of cereal based supplement in the diet increased the risk of high SCC compared to supplementation with polyunsaturated fatty acids. According to Fedele et al. (1996) high SCC could be associated with imbalances of energy and protein, whereas Madsen \& Nielsen (1981) found no significant differences in SCC attributable to protein level of rations. For all treatments the concentration of urea measured in the milk was within the recommended interval from 3 to 5 mmol/l (Bang \& Strudsholm, 1993). A positive relation has been found between PBV and the content of urea in the milk (Bang \& Strudsholm, 1993) and between crude protein in the ration and urea content in milk (Westwood et al., 1998; Ropstad et al., 1989). This was also the case for the present experiment.

In conclusion, compared to a supplement of barley, supplement of a concentrate mixture resulted in a higher milk yield. This may be explained by the desirability of a balanced diet. Supplement of fodder beets compared to barley resulted in a milk yield reduction, which could be expected because of the lower energy supply. Supplement of fibrous grass pellets instead of barley at the same DM level resulted in the same milk yield. This may be due to a positive effect of grass pellets on the diet composition, as the grass pellet fed cows probably have not compensated for the lower energy supply from supplementary feed with a higher intake of ad libitum feed. In all experiments the higher level of starch in the barley treatments did not result in the lower milk fat percentage expected, probably because a high level of roughage and the high frequent allocation of the starch resolved the negative effect on the milk fat percentage.

\section{Acknowledgements}

The authors express their thanks to the farmers Erik Andersen, Leif Mortensen, and Søren Degn for hosting the experiments, the research assistants Niels Thomsen and Gunnar Grønning, and the farm advisers Anders Møller, Dorte Bossen and Christine Schleisner for the on-farm registration.

\section{References}

Aaes, O. 1991. Dried grass pellets as substitute for concentrates for dairy cows. Report for KISAM. 16-33. (In Danish.)
Agabriel, C., Coulon, J. B., Journal, C. \& Bony, J. 1997. Effect of concentrate type and distribution method on milk fat content and milk production in dairy cows. Ann. Zootech. 46, 417-425.

Bang, H. G. \& Strudsholm, F. 1993. Urea content of milk, as a control of the protein supply of the dairy. Report 34. The National Committee on Cattle Husbandry. Denmark. 45 pp. (In Danish.)

Barnouin, J., Chassagne, N. \& Aimo, I. 1995. Dietary factors associated with milk somatic cell counts in dairy cows in Brittany, France. Preventive Veterinary Medicine. 21, 299-311.

Beukelen, P. V. 1983. Studies on milk fat depression in high producing dairy cows. $\mathrm{PhD}$ thesis, University of Utrecht. $268 \mathrm{pp}$.

Birkenmaier, F., Schwarz, F. J., Müller, H. L. \& Kirchgessner. 1996. Feed intake and milk performance of dairy cows fed fodder beets together with grass silage. Arch. Anim. Nutr. 49, 335-347.

Castle, M. E., Gill, M. E. \& Watson, J. N. 1981. Silage and milk production a comparison between barley and dried sugar beet pulp as silage supplements. Grass and Forage Sci. 36, 319-324.

Council for the European Union. 1999. Ordinance No 1804/1999 of July 1999. Supplementing Regulation (EEC) No 2092/91. Official Journal of the European Union L222. Bruxelles. 28 pp.

Cressman, S. G., Grieve, D. G., Macleod, G. K., Wheeler, E. E. \& Young, L. G. 1980. Influence of dietary protein concentration on milk production from dairy cattle in early lactation. J. Dairy Sci. 63, 1839.

DePeters, E. J. \& Cant, J. P. 1992. Nutritional factors influencing the nitrogen composition of bovine milk: a review. J. Dairy Sci. 75, 2043-2070.

Edwards, J. S., Bartley, E. E. \& Dayton, A. D. 1980. Effects of dietary protein concentration on lactating cows. J. Dairy Sci. 63, 243.

Fedele, V., Claps, S. \& Rubino, R. 1996. Effect of feeding system on somatic cell count in goats: somatic cells and milk of small ruminants. Proceedings. Bella. Italy. 25-29 September. EAAP publication No 77. 167-174.

Garnsworthy, P. C. 1989. The interaction between dietary fibre level and protein degradability in dairy cows. Anim. Prod. 48, 271281.

Griinari, J. M., Chouinard, P. Y. \& Bauman, D. E. 1997. Trans-fatty acids hypothesis of milk fat depression revised. Proceedings of the 1997 Cornell Nutrition Conference. 208-216.

Helrich, K. 1990. Official methods of the analysis of the AOAC. $15^{\text {th }}$ edition. Association of the Official Analytical Chemists. 684 pp.

Huhtanen, P. 1987. The effects of dietary inclusion of barley, unmolassed sugar beet pulp and molasses on milk production, digestibility and digesta passage in dairy cows given silage based diet. J. of Agric. Sci. in Finland 59, 101-120.

Huhtanen, P. 1992. The effects of barley versus barley fibre with or without distillers soluble's on site and extent of nutrient digestion in cattle fed grass silage based diet. Animal Feed Science Technology 36, 319-337.

Huhtanen, P. 1993. The effect of concentrate energy source and protein content on milk production in cows given grass silage ad libitum. Grass and Forage Sci. 48, 347-355.

Jackson, D. A., Johnson, C. L. \& Forbes, M. 1991. The effect of compound composition on silage intake, feeding behaviour, production of milk and live-weight change in lactating dairy cows. Anim. Prod. 52, 11-19.

Kristensen, V. F. 1983. Management of feed intake by composition of the feed ration and choice of feeding principle. In: Optimum feeding of the dairy cow. Feed composition, feed intake, metabolism and production. Østergaard, V. \& Neiman-Sørensen, A. (eds.). Report 551. DIAS, Denmark. 7.1-7.35. (In Danish.)

Kristensen, V. F. 1995. Prediction of feed intake in dairy cows. In: The nutrition of dairy cows. Internal report 61. DIAS, Denmark. (In Danish.) 


\section{Mogensen and T. Kristensen}

Kristensen, T. \& Aaes, O. 1998. Supplementary feeding of dairy cows at continuous grazing: influence of the protein value of the supplement on production, reproduction and health. Report 3. DIAS, Denmark. 1-39. (In Danish.)

Krohn, C. C. \& Andersen, P. E. 1979. Rations with beet or barley fed separately or in complete rations for dairy cows. Report 480 . DIAS, Denmark. 1-28. (In Danish.)

Lundquist, R. G., Johnson, D. G. \& Otterby, D. E. 1981. Percentage and source of protein in complete rations fed in early lactation. J. Dairy Sci. 64, 143.

Madsen, P. S. \& Nielsen, S. M. 1981. The influence of udder health when feeding different levels of protein. Proceedings of $\mathrm{IV}^{\text {th }}$ International Symposium on Mastitis Control. 2, 463-476.

Mayne, C. S. \& Gordon, F. J. 1984. The effect of type and level of concentrate feeding on milk production. Anim. Prod. 39, 65-76.

Moate, P. J., Dalley, D. E., Roche, J. R., Grainger, C., Hannah, M. \& Martin, K. 1999. Turnips and protein supplements for lactating dairy cows. Australian Journal of Experimental Agriculture 39, $389-400$.

Mogensen, L. \& Kristensen, T. 2002. Effect of barley or rape seed cake as supplement to silage for high-yielding organic dairy cows. Acta Agric. Scand. 52; 4, 243-252.

Mogensen, L., Kristensen, T. \& Kristensen, I. S. 1999. Organic cattle production. Technical and economic results from farm studies 1997-98. Typical level of organic milk production in Denmark. Report 10. DIAS, Denmark. 138 pp. (In Danish.)

Murphy, M. 1989. The influence of non-structural carbohydrates on rumen microbes and rumen metabolism in milk producing cows. Report 183, Department of Animal Nutrition and Management, Swedish University of Agricultural Sciences, Uppsala, Sweden. 162 pp.

Phipps, R. H., Sutton, J. D., Weller, R. F. \& Bines, J. A. 1987. The effect of concentrate composition and method of silage feeding on intake and performance of lactating dairy cows. J. of Agric. Sci. Cambridge 109, 337-343.

Roffler, R. E. \& Tracker, D. L. 1983. Early lactational response to supplemental protein by dairy cows fed grass-legumes forage. J. Dairy Sci. 66, 2100-2108.

Ropstad, E., Vik-Mo, L. \& Refsdal, A. O. 1989. Levels of milk urea plasma constituents and rumen liquid ammonia in relation to the feeding of dairy cows during early lactation. Acta Vet. Scand. 30, 199-208.

SAS, 1990. SAS/STAT User's Guide, Vol. 2. Vers. 6, $4^{\text {th }}$ edition. Gary, NC. 893-1686.
Sjaunja, L. O., Baevre, L., Junkkarinen, L., Pedersen, J. \& Setälä, J. A. 1990. Nordic proposal for an energy-corrected milk (ECM) formula. ICRPMA. $27^{\text {th }}$ session, Paris $2-6$ July.

Spörndly, E. 1989. Effect of diet on milk composition and yield of dairy cows with special emphasis on milk protein content. Swedish J. Agric. Res. 19, 99-106.

Stensig, T., Weisbjerg, M. R. \& Hvelplund, T. 1998. Digestion and passage kinetics of fibres in dairy cows as affected by the proportion of wheat starch or sucrose in the diet. Acta Agri. Scand. 48, 129-140.

Strudsholm, F., Nielsen, E. S., Flye, J. C., Kjeldsen, A. M., Weisbjerg, M. R., Søegaard, K., Kristensen, V. F., Hvelplund, T. \& Hermansen, J. E. 1997. Feed tables. Composition and nutritional value for cattle. Report 69. The National Committee on Cattle Husbandry. Denmark. 53 pp. (In Danish.)

Strudsholm, F., Aaes, O., Madsen, J., Kristensen, V. F., Andersen, H. R., Hvelplund, T. \& Østergaard, S. 1999. Danish feed recommendations for cattle. Report 84. The National Committee on Cattle Husbandry. Denmark. 47 pp. (In Danish.)

Sutton, J. D., Bines, J. A. \& Napper, D. J. 1985. Comparison of starchy and fibrous concentrates for lactating dairy cows. Anim. Prod. 40, 533.

Tilley, J. M. A. \& Terry, R. A. 1963. A two-stage technique for the in vitro digestion of forage crops. J. British Grassl. Soc. 18, 104111.

Thomas, C., Aston, K., Daley, S. R. \& Bass, J. 1986. Milk production from silage. 4 . The effect of the composition of the supplement. Anim. Prod. 42, 315-325.

Valk, H., Poelhuis, H. W. K. \& Wentink, H. J. 1990. Effect of fibrous and starchy carbohydrates in concentrate as supplements in a herbage based diet for high-yielding dairy cows. Netherlands J. Agric. Sci. 38, 475-486.

Weisberg, M. R. 1997. Recirculation of nitrogen to the rumen. Internal Report 88. DIAS, Denmark. 18-29. (In Danish.)

Westwood, C. T., Lean, I. J. \& Kellaway, R. C. 1998. Indications and implications for testing of milk urea in dairy cattle: a quantitative review. New Zealand Vet. J. 46, 87-96.

Visser, H. D. 1984. Krachtvoer voor hoogpruktief melkvee in rantsoenen met snijmais.: Bedrijfsontwikkeling. 15, 383-389.

Visser, H. D., Togt, P. L. \& Tamminga, S. 1990. Structural and nonstructural carbohydrates in concentrate supplements of silagebased dairy cow rations. 1. Feed intake and milk production. Netherlands J. Agric. Sci. 38, 487-498. 